\title{
Jan Kozubowski
}

University of Warsaw

College of Interdisciplinary Individual Studies in Humanities and Social Sciences

e-mail:kozubowskijan@gmail.com

\section{Pieniądz jako towar fikcyjny - utopia liberalizmu według Karla Polanyiego}

\section{Money as a fictitious commodity - liberal utopia according to Karl Polanyi}

This article concerns Karl Polanyi's theory of money as a fictitious commodity and its importance for understanding liberal ideology. According to the Hungarian economist, money is not a commodity but a social relation between the debtor and the creditor. Therefore, the complete commodification of money is part of a liberal utopia, as it is associated with a counter-movement and an economic crisis, two processes that make impossible the constitution of a market society. The author analyzes the problem of counter-movement through the prism of Karl Mannheim's theory of utopia and ideology. The final part of the article deals with the problem of economic crises, Polanyi's views on the nature of economic breakdown are compared with contemporary reflection on the role of money in financial markets.

Keywords: Karl Polanyi, money, Karl Mannheim, commodification, liberalism, utopia

JEL Classification: B25

\section{Wprowadzenie}

W Wielkiej transformacji Karl Polanyi (2010) opisał powstanie społeczeństwa opartego na samoregulującym się rynku, kształtującego się w XIX wieku. Instytucje społeczne, które wcześniej nie były postrzegane jako towary, w systemie gospodarki 
rynkowej zostały poddane prawom podaży i popytu. Dotyczyło to przede wszystkim trzech kluczowych elementów kultury człowieka - pracy, ziemi i pieniądza, których rynkową formę Polanyi nazwał towarami fikcyjnymi. Powołując się na pisma Karla Mannheima, postaram się pokazać, że program ich utowarowienia, który implicite zakładała ideologia liberalna ${ }^{1}$, jest niemożliwy do zrealizowania. „Ideologia” jest w tym przypadku słowem kluczowym, albowiem - jak wskazuje Polanyi - ziemia, praca oraz pieniądz nie mogą zostać całkowicie urynkowione, stąd ich towarowa „fikcyjnośćc. Ideologia liberalna stanowi przykład - słowami Mannheima (2008, s. 70) - grupowej „nieświadomości społecznej”, dąży do społeczeństwa rynkowego, nie dostrzegając jednak, że jest to cel nieosiągalny. Jak wskazuje Karl Polanyi (2010, s. 4), „doskonałe” społeczeństwo rynkowe jest niemożliwe, albowiem samo sobie zaprzecza (pozbawia słowo „społeczeństwo” jego treści): „taka konstrukcja nie mogła (...) istnieć przez dłuższy czas, nie unicestwiając jednocześnie ludzkich i przyrodniczych podstaw istnienia społeczeństwa". Możliwy jest oczywiście proces urynkawiania społeczeństwa i to jego dotyczy artykuł.

Ideologiczność liberalizmu najlepiej można zobrazować na przykładzie fikcyjności pieniądza towarowego. Chociaż teoria Polanyiego dotycząca pieniądza jako towaru fikcyjnego nie została kompleksowo opracowana przez jego komentatorów (Savevska, 2019, s. 30), w ramach teoretycznej recepcji tej idei można wyróżnić dwa nurty interpretacyjne. Pierwszy z nich tworzą autorzy analizujący fragmenty Wielkiej transformacji, w których Polanyi dekonspiruje ortodoksyjną ideologię postrzegającą pieniądz jako towar. Kluczowe znaczenie ma w tym kontekście analiza historyczna systemu waluty złotej. Drugi nurt „uwspółcześnia” analizę Polanyiego, wskazując, że współczesne rynki finansowe są najlepszym przykładem utowarowienia pieniądza. Niniejszy artykuł będzie próbą połączenia tych dwóch perspektyw, na wstępie zrekonstruuję więc teorię pieniądza jako towaru fikcyjnego, w dalszej części postaram się zaaplikować narzędzia teoretyczne Polanyiego i innych przedstawicieli czartyzmu do analizy współczesnego kapitalizmu. Omawiane perspektywy - teoretyczną (historyczną) i praktyczną (współczesną) - łączy wspólna podstawa: obie wskazują, że liberalizm gospodarczy traktuje pieniądz jak rzecz - towar mający pewną wartość wewnętrzną.

\section{Liberalizm i fikcyjność pieniądza towarowego}

Teoria pieniądza jako towaru fikcyjnego, rozwinięta przez Polanyiego, jest problematyczna. Można mieć wątpliwości, czy jego koncepcję powinno się nazywać teorią; należałoby raczej powiedzieć, że w Wielkiej transformacji Polanyi przed-

\footnotetext{
${ }^{1}$ Chodzi tutaj o „liberalizm” w znaczeniu używanym przez Polanyiego oraz Mannheima, a więc o klasyczny liberalizm XIX wieku. W Ideologii i utopii Mannheim (2008, s. 259) opisuje „utopię liberalno-humanitarną” od strony społecznej - wskazuje, że grupowym „nośnikiem” tej świadomości była klasa średnia. Polanyi skupia się na ideach ekonomistów klasycznych i ich oddziaływaniu na politykę gospodarczą i społeczną (zob. Polanyi, 2010, s. 163). Jak pokazują jednak Block i Somers (2020, s. 38), analizy dotyczące klasycznego liberalizmu wcale się nie zdezaktualizowały - współcześnie mogą stanowić punkt odniesienia do krytyki ideologii liberalizmu.
} 
stawia luźny zbiór tez o współczesnym charakterze pieniądza, zbiór, który z pewnością wymaga uzupełnienia. Pojęcie pieniądza jako towaru fikcyjnego pojawia się jedynie w Wielkiej transformacji, w późniejszych pismach antropologicznych dotyczących pieniądza Polanyi je porzuca. Mimo że autor nie poświęcił tej myśli w swoich pismach zbyt dużo miejsca, wydaje się, że stanowi ona nierozerwalną - i kluczową - część jego całościowej teorii społeczeństwa rynkowego opartego na wykorzenionym rynku. Biorąc to pod uwagę, można wyróżnić dwa poziomy omawianej koncepcji. Pierwszy z nich można nazwać poziomem ogólnym. Według Polanyiego pieniądz z natury nie jest towarem, jednak proces wielkiej transformacji społeczeństwa sprawił, że sztucznie zmieniono go w przedmiot, którym można handlować. Pieniądz zaczął mieć cenę, mógł tracić i zyskiwać wartość. W najogólniejszej formie omawiana fikcja wiązałaby się z podporządkowaniem pieniądza prawom podaży i popytu, a więc pozbawiałaby społeczeństwo kontroli nad nim. Z takiej perspektywy wydaje się jasne, że w społeczeństwach nierynkowych nie mamy do czynienia $z$ towarową fikcyjnością pieniądza.

Z kolei na poziomie analizy przedmiotowej, odnoszącej się do konkretnego przypadku historycznego (krajów zachodnich przed drugą wojną światową), fikcyjność systemu monetarnego byłaby pochodną powiązania walut krajowych z cennym kruszcem, a więc złotem czy srebrem. Wprowadzenie takiego systemu miało daleko idące konsekwencje, powstał bowiem ogólnoświatowy rynek pieniądza, który - według Polanyiego - zyskał władzę nad państwami narodowymi. Decyzje międzynarodowych podmiotów finansowych zaczęły mieć decydujący wpływ na działanie gospodarek krajowych. Chociaż według Polanyiego pieniądz zawdzięcza istnienie państwu, powiązanie go z kruszcem sztucznie przenosi władze nad nim „na zewnątrz” państwa. Trzeba w tym miejscu zauważyć, że według Polanyiego powstanie gospodarki rynkowej nie było naturalnym procesem, wynikało za to z konkretnych decyzji politycznych podejmowanych w ramach wpływowej ideologii liberalnej. Można więc dojść do paradoksalnego wniosku, że państwa „same z siebie” pozbawiły się władzy nad pieniądzem i oddały ją rynkowi. Ten element teorii węgierskiego myśliciela wpisuje się w kontekst Wielkiej transformacji, opiera się więc na koncepcji wykorzenienia rynku ze społeczeństwa. Wykorzenienie polegało na stworzeniu oddzielnego pola społecznego, w którym dominowała relacja wymiany. Polanyi (1957, s. 68) wskazuje, że początek tego procesu wiąże się z upowszechnieniem pieniądza jako środka wymiany.

Czemu sprzeciwiał się Polanyi, formułując taką koncepcję fikcyjnego towaru? Odpowiedź jest prosta: ideologii liberalnej, sprowadzającej pieniądz do złotych i srebrnych monet, które w pewnym momencie rozwoju historycznego zastąpiły barter. W ramach podziału na tzw. analizę realną i analizę monetarną, który przeprowadził Schumpeter, liberalna teoria ekonomiczna zawiera się w pierwszej grupie. Z liberalnej perspektywy pieniądz jest tylko skutkiem ubocznym wymiany, „technicznym urządzeniem ułatwiającym wymianę” (Schumpeter, 2006, s. 264). Ten ortodoksyjny pogląd dotyczący pieniądza podkreśla jego funkcję jako środka wymiany, a więc towaru, który minimalizuje rynkowe koszty transakcyjne. W skróconej formie pogląd ten przedstawił John Stuart Mill (1885, s. 499): „(..) wartość pieniądza, tak jak wszystkich towarów, determinowana jest przez popyt 
oraz podaż"2. Polanyi zauważył, że ta fikcja z jednej strony przyczyniła się do powstania ekonomii jako nauki, z drugiej zaś stanowi najważniejsze teoretyczne ograniczenie tejże dyscypliny. Liberalizm teoretycznie zignorował bowiem powstanie i rozwój systemu kredytowego. Stanowi to paradoks, że liberalizm, który za pomocą narzędzi inżynierii społecznej właściwie przyczynił się do powstania systemu kapitalistycznego, jednocześnie nie zauważał kluczowego skutku wprowadzanych reform, a więc powstania pieniądza kredytowego, którego dynamiczny rozwój uważany jest za kluczową cechę odróżniającą kapitalizm od innych systemów gospodarczych (Ingham, 2004, s. 13). Tworząc koncepcję pieniądza towarowego, ideologicznie zasłonił powstanie systemu kapitału, a więc pieniądza, który nie ma powiązania ze sferą realną gospodarki, tzn. z obrotem rzeczywistymi towarami.

W takim kontekście nie ma znaczenia, czy za pieniądz uznamy sztabki złota czy pewien rodzaj aktywa finansowego - w obu przypadkach mamy do czynienia z performatywnym traktowaniem pieniądza, jakby był on towarem (zob. Block i Somers, 2020, s. 141). W obu przypadkach kontrola nad podażą pieniądza zostaje przeniesiona „na zewnątrz” społeczeństwa: w pierwszym uzależniona jest od podaży złota, w drugim - od rynku finansowego. Jak postaram się pokazać, pieniądz nie jest jednak towarem $z$ dwóch powodów. Po pierwsze, traktowanie go tak, jakby nim był, wiąże się z rozszerzeniem stosunku pieniężnego na coraz większą liczbę instytucji - to zaś wywołuje kontrruch. Po drugie, współcześnie utowarowienie pieniądza wiąże się z coraz większą finansjalizacją ekonomii, co jest z kolei przyczyną kryzysów. Te dwie przyczyny - społeczna i ekonomiczna - przesądzają o utopijności liberalnego podejścia do pieniądza i gospodarki.

\section{Spoleczna utopia liberalizmu - kontrruch}

Dlaczego ziemia, praca i pieniądz stanowią według Polanyiego podstawę kultury człowieka? Według węgierskiego ekonomisty ziemia uosabia środowisko, w którym działa człowiek, któremu nadaje znaczenie i z którego może czerpać zasoby. Praca, poprzez którą człowiek przekształca naturę w produkt społeczny, jest wolną, kreatywną aktywnością jednostki. Z kolei „[p]ieniądz i kredyt są organizacją społeczną samą w sobie, która łączy ze sobą człowieka oraz jego zasoby" (Drucker, 1993, s. 256).

Ani pieniądz, ani kredyt nie są więc towarami, ponieważ nie są produkowane „po to, by zostać sprzedane na rynku” (Polanyi, 2010, s. 88). Co więcej - one w ogóle nie są produkowane, są niejako naturalnym ,zasobem” człowieka. Jak wskazuje Polanyi (1977, s. 97), „pieniądze powinny zostać zdefiniowane jako system semantyczny, bardzo podobny do języka, pisania lub wagi i miary". Pieniądze są środkiem komunikacji między różnymi podmiotami i grupami społecznymi, przede wszystkim między dłużnikami a pożyczkodawcami. W ramach tego

\footnotetext{
${ }^{2}$ Cytat pochodzi z oryginalnej, angielskiej wersji Zasad ekonomii politycznej Milla. W polskim thumaczeniu ten fragment został błędnie przetłumaczony.
} 
,języka" każdy symbol jest pewnym abstraktem, znajdującym się w systemie symboli: może coś znaczyć tylko w odniesieniu do innego symbolu. Tak więc pieniądze mają różne znaczenia w zależności od systemu społecznego, w którym występują. Na przykład miedziane płytki - zwane „miedziakami” - używane przez północnoamerykańskie plemię Kwakiutlów mają pewne znaczenie tylko w odniesieniu do charakterystycznej dla tego plemienia kultury prestiżu i ostentacyjnej konsumpcji (Benedict, 2007, s. 378). Z kolei współczesne znaczenie pieniędzy określa się w stosunku do własności prywatnej (Wennerlind, 2001, s. 564).

Pieniądz tworzy więc system symboliczny, w którym powiązanie między fizycznym przedmiotem a przypisaną mu wartością jest historycznie przygodne (Codere, 1968, s. 560), albowiem system jako całość opiera się na zaufaniu i zależy od społecznych reguł panujących w danej epoce i kulturze. Właśnie dlatego, według Polanyiego, ,pieniądze nie powinny być postrzegane jako rzecz, ale jako instytucja, która zarządza emisją, wyceną oraz umorzeniem długów" (Maucourant, 1995, s. 9). W związku z tym, że język pieniądza wyraża relację dłużnik-wierzyciel, a pieniądz przedmiotowy, dzięki funkcji płatniczej, jest formą umarzania długów (Polanyi, 1977, s. 119), kluczowe znaczenie ma w tym przypadku zaufanie do społecznych reguł panujących w danym „kręgu gospodarczym” (Simmel, 2012, s. 192). Reguły tego języka są gwarantowane przez ośrodek legalnej władzy centralnej (państwo). Jest to pogląd zgodny z teorią Simmla (s. 190): „Bez zaufania społeczności do rządu dokonującego emisji (...) nie może dojść do obrotu gotówkowego. Napis na monetach maltańskich: non aes sed fides [nie spiż lecz wiara] trafnie określa intrygujący wpływ wiary, bez którego nawet pełnowartościowa moneta (...) nie mogłaby wypełniać swojej funkcji”. Jak pokazał David Graeber (2018), relacja długu jest prastarą relacją, która przez wieki integrowała członków różnych społeczności. Pieniądz jest więc systemem symbolicznym opartym na długu, konkretniej: jest symbolem siły nabywczej, wartości czyjegoś długu. Właśnie dlatego John Maynard Keynes w Traktacie o pieniądzu podkreśla tezauryzacyjną funkcję pieniądza: potrzeba przeliczenia długu danej jednostki czy rodziny powoduje powstanie ,pieniędzy rachunkowych” (money of account). Pieniądz ten powstaje przez zaksięgowanie długu (Keynes, 2013, s. 3). Dany przedmiot może być środkiem przechowywania siły nabywczej tylko o tyle, o ile można nim spłacić dług. Dlatego, w myśl tej wczesnej koncepcji Keynesa, państwo ma kluczowe znaczenie, ponieważ powoduje, że długi są zwracane - to znaczy pieniądze są powszechnie akceptowane. Władza potwierdza więc legalność abstrakcyjnej wartość przypisywanej danemu przedmiotowi (Mellor, 2010, s. $9-10,14)$.

Taka koncepcja wyraźnie odbiega od klasycznej teorii pieniądza kruszcowego, według której pieniądz posiada wartość sam w sobie, ponieważ jest towarem (np. złotą lub srebrną monetą). Polanyi za Marksem przyjmuje, że pieniądz rynkowy jest czymś historycznie nowym. „Fetyszyzacja pieniądza polega na tym, że dostrzega się tylko jego istnienie przedmiotowe, «metaliczne». Nie widzi się natomiast «pieniężnej duszy», która przenika wszystkie ogniwa produkcji i wymiany towarowej. Inaczej mówiąc, Marks wytyka klasycznej ekonomii politycznej, że w pieniądzu widzi «przedmiot», a nie funkcję [...]” (Skrzypek, 1992, s. XXII). 
Słowami Simmla (2012): język pieniądza (system znaków) w klasycznej ekonomii został ideologicznie sprowadzony do jego wartości substancjalnej, przedmiotowej. Przeświadczenie o towarowym charakterze pieniądza jest pokłosiem teorii wywodzącej jego istnienie $\mathrm{z}$ barteru i niesie różne skutki w zależności od epoki historycznej. W czasach Polanyiego prowadziło do powiązania pieniądza ze złotem, dzisiaj wiąże się z „handlem pieniądzem” i aktywami finansowymi na rynkach finansowych. Niniejsza część artykułu odnosi się do socjologicznych skutków owej fetyszyzacji pieniądza jako „rzeczy” - czy to w postaci złota, czy gry giełdowej, czy papierów wartościowych.

Właśnie dlatego, że pieniądz jest systemem komunikacji społecznej, nie ma on z natury rynkowego charakteru (Polanyi, 1977, s. 77). Jak wskazuje Polanyi, dopiero w społeczeństwie rynkowym pieniądz, handel i rynek występują razem, a raczej należałoby powiedzieć, że pieniądz i handel są poddane prawom rynku. Pierwotne pieniądze (nierynkowe) Polanyi nazywa „specjalno-celowymi” (special-purpose) - mają one różną podstawę materialną w zależności od celu, któremu służą. Funkcję standardu wartości, tezauryzacji, środka wymiany spełniają jakościowo różne przedmioty (s. 98-103). Z kolei w społeczeństwie rynkowym pieniądz spełnia wszystkie wyżej wymienione funkcje, co sprawia, że „fizycznie różne przedmioty stają się (...) «towarami»" (Dalton, 1961, s. 13). Podsumowując: „Współczesna (...) idea pieniądza uniwersalnego (all-purpose) jest mentalnym produktem ideologii pieniądza-towaru" (Maucourant, 1995, s. 13).

$\mathrm{Na}$ tym etapie analizy narzuca się jednak ważne pytanie: $\mathrm{z}$ czego właściwie wynika ideologiczność liberalizmu. Skąd wziął się aksjomat pieniądza-towaru? Według Polanyiego podstawowy błąd poznawczy liberalizmu polega na tym, że ontologizuje on typ idealny wymiany rynkowej. Rozbudowane konstrukcje teoretyczne sprowadza zazwyczaj do hipotetycznej sytuacji wymiany handlowej między dwoma równymi sobie podmiotami. Współczesne podręczniki do ekonomii, które odwołują się do takich podstawowych typów idealnych, opisują kapitalizm, który już dawno nie istnieje, a więc jako system opierający się na relacji wymiany między równymi sobie podmiotami, podczas gdy dzisiejszy kapitalizm ma charakter monopolistyczny i jest zdominowany przez wielkich graczy giełdowych. W podręcznikowej sytuacji pieniądz (w formie złotych czy srebrnych monet) po prostu ułatwia zawarcie danej transakcji rynkowej. Liberalizm nie dostrzega faktu, że taki stosunek do pieniądza pozwala na handlowanie nim jak zwyczajnym towarem, to zaś powoduje, że rzeczywistym „producentem” pieniądza staje się rynek finansowy. Postulat wolności gospodarczej wręcz zachęca, by pieniądz postrzegać jako formę inwestycji, by za pomocą jego kupna i sprzedaży wygenerować dodatkowy pieniądz. Można się więc zgodzić z Mikołajem Lewickim (2019, s. 103): „Polanyi wskazuje, że gdy pieniądz służy wyłącznie generowaniu innego pieniądza, a więc staje się towarem, wytwarza fikcję - bycia pośrednikiem i środkiem płatniczym, realnie zaś jest po prostu kapitałem". Warto jednak zauważyć, że Polanyi nie używa w swoich pismach pojęcia kapitału (Jessop, 2019, s. 81), nie chodzi tutaj więc o kapitał w rozumieniu ekonomii neoklasycznej - a więc postrzegany jako jeden z czynników produkcji. Nie chodzi również o kapitał w sensie marksistowskim, a więc o przywłaszczenie przez kapitalistów wartości dodat- 
kowej. Kapitał należy w tym przypadku rozumieć jako formę pieniądza kredytowego, oderwanego od sfery realnej gospodarki. Ideologiczność liberalizmu wynika więc $\mathrm{z}$ faktu, że podmioty gospodarcze traktują pieniądz tak, jakby był towarem, jednocześnie nie dostrzegając, jakie skutki niesie takie działanie.

Liberalizm nie dostrzega więc, że utowarowienie pieniądza wymaga utowarowienia innych instytucji społecznych, poszerzenia definicji „towaru” o pieniądz, pracę oraz ziemię, by możliwy stał się ich użytek inwestycyjny. Wraz z wprowadzeniem pieniądza „uniwersalnego” całe społeczeństwo rynkowe zaczyna opierać się na „fikcji towarowej” (Polanyi, 2010, s. 88). To właśnie jej sprzeciwiają się kontrruchy - oddolne wystąpienia ludności pragnącej ochronić społeczeństwo przed sztucznie narzuconym mechanizmem rynkowym.

Koncepcję kontrruchu Polanyiego można pogodzić z dialektyką dwóch form świadomości klasowej - ideologii i utopii - przedstawioną przez Karla Mannheima. Według socjologa wiedzy - w dużym skrócie - utopia podważa panujące stosunki społeczne, ideologia zaś stara się je uzasadnić. Wraz ze zdobyciem władzy przez daną klasę społeczną utopijna świadomość tej grupy zamienia się w ideologię (zob. Kozubowski, 2018, s. 70). Każda ideologia (w szerokim sensie tego słowa, rozumiana jako światopogląd) składa się z elementów utopijnych i ideologicznych. Jest o tyle utopijna, o ile doprowadziła do postępu historycznego, a więc o ile jej postulaty zostały zrealizowane. Z kolei jej ideologiczność wynika z niemożności zrealizowania niektórych głoszonych przez nią postulatów. Właśnie w takim kontekście można mówić o dziewiętnastowiecznej utopii liberalnej, którą opisywał Polanyi. Występując przeciwko feudalizmowi, postulowała ona radykalne wykorzenienie rynku z relacji społecznych. Można powiedzieć, że program ten był utopijny, ponieważ zrewolucjonizował stosunki społeczne, doprowadzając - słowami Polanyiego - do „kataklizmu” wielkiej transformacji. Był jednak ideologiczny, ponieważ nie mógł zostać całkowicie zrealizowany.

Wraz ze zdobyciem pozycji dominującej utopia liberalna doprowadziła do rewolucji stosunków społecznych - podporządkowała społeczeństwo rynkowi. Taki stan Polanyi nazywa społeczeństwem rynkowym. Przejście na pozycje ideologiczne wiązało się z podjęciem działań politycznych, które traktowały pieniądz, ziemię oraz pracę tak, jakby były one towarami. Na tym właśnie polega ,[s]krajna sztuczność gospodarki rynkowej (...)” (Polanyi, 2010, s. 8). Świadomość ideologiczna nie może dostrzec sprzeczności, które wynikają z takiego działania, albowiem wiązałoby się to $\mathrm{z}$ upadkiem całego liberalnego przedsięwzięcia. Tak też Mannheim opisuje postulat wolności, który liberałowie nieśli na sztandarach w okresie utopijnym. Ideologiczność tego postulatu wynika z niemożności jego całkowitego zrealizowania, postępowano więc tak, jakby wolność już była wszystkim zapewniona. Właśnie przeciwko takiemu zachowaniu występował nowy kontruch - ruch robotniczy - wraz ze swoim noologicznym przedstawicielstwem - utopią socjalistyczną, który domagał się „rzeczywistej” wolności. Istniała jednak również druga odpowiedź na system liberalizmu - faszyzm. Mannheim i Polanyi są zgodni, że faszyzm był pewnym typem kontruchu (Polanyi, 2010, s. 184) (utopii w przypadku Mannheima) i przybrał na sile dzięki kryzysom, które „rozluźniają ustrój kapitalistyczno-mieszczański” (Mannheim, 2008, s. 180). 
Widać więc wyraźnie, że koncepcję pieniądza jako towaru fikcyjnego można przedstawić jako teorię ideologii pieniądza. Performatywnie zrównuje ona pieniądz $\mathrm{z}$ towarem, nie zauważając, że przyczynia się $\mathrm{w}$ ten sposób do powstania systemu handlu pieniądzem, który niszczy dawne struktury społeczne i wywołuje kontrruch. Ten ostatni jest w tym przypadku utopią występującą przeciwko ideologii „fundamentalizmu rynkowego” (Block i Somers, 2020). To właśnie sprzeciw konkretnych grup społecznych nie pozwala na „domknięcie” liberalnego społeczeństwa, uniemożliwia jego stabilizację. Można więc powiedzieć, że proces „rynkowienia” pieniądza jest utopią, niedokończonym projektem.

Chociaż stosunek Mannheima i Polanyiego do liberalizmu należy uznać za niejednoznaczny (nie ukrywali przywiązania do wartości liberalnych, jednocześnie otwarcie sympatyzując z ruchami socjalistycznymi; Kassner, 2019, s. 33-34), obaj zgadzali się co do ideologiczności liberalnego przedsięwzięcia. Syntetyzując omówione wyżej wątki teorii obu myślicieli, można wyróżnić trzy powody, które sprawiają, że liberalizm jest ideologią. Po pierwsze, liberalny program gospodarczy jest niemożliwy do zrealizowania, wiązałby się bowiem z wyniszczeniem społeczeństwa. Sztuczność społeczeństwa rynkowego wynika z utopijnego charakteru liberalizmu, mówiąc prościej: supremacja rynku nad społeczeństwem wynika z sukcesów omawianej ideologii. Sam proces urynkawiania jest jednak destabilizujący. Dochodzimy więc do drugiego powodu ideologiczności liberalizmu - proces urynkawiania wywołuje kontrruch, który można postrzegać jednocześnie jako symptom problemów społeczeństwa rynkowego oraz jego antytezę. Po trzecie, liberalizm nie zauważa tych problemów, opiera się na dedukcyjnie wyprowadzanym indywidualizmie, który opisuje hipotetyczną sytuację wymiany rynkowej i ignoruje rynki finansowe.

\section{Ekonomiczna utopia liberalizmu - kryzys}

Oprócz sprzeciwu społeczeństwa, jaki wywołuje liberalizm, Polanyi wymienia jeszcze jedną - tym razem ekonomiczną - przyczynę jego utopijności. Społeczeństwo rynkowe narażone jest na ciągłe kryzysy, które pojawiają się wraz z urynkowieniem pieniądza oraz wycofaniem się państwa z kontroli rynków. W tym przypadku kluczowe znaczenie dla analizy ekonomicznych skutków utowarowienia pieniądza ma dla Polanyiego $\mathrm{z}$ jednej strony proces powstania systemu waluty złotej, zaś z drugiej - powstanie tzw. haute finance (ogromnych fortun, wyższej finansjery) (Seccareccia i Correa, 2015, s. 4). Oba procesy pozbawiły państwo kontroli nad pieniądzem i sprawiły, że przypływ gotówki do produktywnego sektora gospodarki został uzależniony od fluktuacji na rynkach finansowych. Ma to szczególne znaczenie w przypadku kryzysów, które rozpoczynają się w świecie finansowym, ale z czasem rozlewają się na całą gospodarkę: „Rynkowa organizacja siły nabywczej okresowo prowadziłaby do likwidacji przedsięwzięć gospodarczych, braki i nadwyżki pieniądza okazałyby się bowiem dla nich równie katastrofalne w skutkach, jak powodzie i susze w społeczeństwach prymitywnych" 
(Polanyi, 2010, s. 89). W społeczeństwie rynkowym pieniądz okazał się bardzo ważnym elementem życia gospodarczego ludzi, ponieważ stał się czynnikiem produkcji. Decyzje inwestycyjne przedsiębiorców zostały uzależnione od jego ceny - stopy procentowej (s. 91). Pieniądz zaczął mieć więc coraz większy wpływ na społeczeństwo, niczym powodzi obawiano się „odpływu kapitału” (s. 30). Powstawały instytucje zajmujące się przewidywaniem zachowań rynku finansowego. Fluktuacje miały bowiem ogromny wpływ na budżety państw narodowych, w nowoczesnym społeczeństwie ,pieniądz stał się osią polityki państwowej” (s. 30; por. Mellor, 2010, s. 140). To z kolei sprawiało, że mieliśmy do czynienia $\mathrm{z}$ błędnym kołem liberalnej polityki: lobby instytucji finansowych wpływało na decyzje polityczne państw narodowych (wymuszając leseferyzm), to z kolei osłabiało państwo i umacniało strukturę haute finance. Można jednak zadać pytanie, jak długo może trwać proces błędnego koła. Wydaje się, że odpowiedź na nie dotyka sedna teorii pieniądza Polanyiego. Proces urynkawiania państwa jest bowiem destabilizujący i to właśnie kryzys gospodarczy wyznacza jego granicę. Przyjmijmy jednak hipotezę, że możliwe jest doskonałe i absolutne urynkowienie pieniądza. Jakie byłyby skutki takiego stanu? Polanyi przedstawił taką hipotetyczną sytuację na podstawie innego czynnika produkcji - pracy. Mówiąc wprost: skomodyfikowanie siły roboczej wiązałoby się z wyniszczeniem, a nawet śmiercią ludzi poddanych eksploatacji rynkowej, człowiek byłby bowiem po prostu traktowany jak rzecz (Polanyi, 2010, s. 89). Ekonomista nie przedstawił jednak analogicznej wizji społeczeństwa w przypadku radykalnego urynkowienia pieniądza. Można jednak dojść do wniosku, że takim typem idealnym byłaby gospodarka, w której właściwie nie istnieje już sfera realna, a wszystkie transakcje dokonywane są w formie spekulacji finansowej. Oczywiste jest, dlaczego taki typ gospodarki nie mógłby istnieć.

Wydaje się, że najlepszym historycznym przykładem ideologii pieniądza towarowego, która wywodziłaby się z liberalizmu, jest ilościowa teoria pieniądza. Stanowiła ona podstawę do sformułowania teorii monetaryzmu i wprowadzenia jej w życie w latach osiemdziesiątych XX wieku. Poniższa część artykułu nie odnosi się bezpośrednio do pism Polanyiego, jej celem jest jednak uwspółczenienie przedstawionych wyżej tez na temat roli pieniądza w społeczeństwie rynkowym.

Chociaż monetaryzm i ilościowa teoria pieniądza nie postulowały powrotu do powiązania pieniądza ze złotem, dążyły do tego, by ,zachowywał się tak, jakby był dobrem rzadkim" (Graeber, 2018, s. 554). Jak wskazuje Ingham (2004, s. 19), ilościowa teoria pieniądza Fishera jest właściwie rozwinięciem klasycznych teorii naturalnych ograniczeń podaży pieniądza (determinowanej przez podaż kruszcu). Chociaż tym razem obeszło się bez reifikacji praw rynkowych w kruszcu, traktowanie pieniądza tak, jakby był szlachetnym metalem, było zabiegiem sztucznym. Kluczowego znaczenia nabrał bank centralny, który, poprzez ścisłą kontrolę bazy monetarnej, miał performatywnie ,wytwarzać” rzadki towar. Jak zauważyli Timo Walter oraz Leon Wansleben (2020, s. 636), taka polityka banku centralnego w Stanach Zjednoczonych oraz Wielkiej Brytanii w latach osiemdziesiątych sprawiła, że w pewnym stopniu zignorowano rozwój systemu finansowego. Trakto- 
wanie pieniądza jak towaru doprowadziło do tego, że działania banku centralnego przyczyniły się do agresywnej finansjalizacji, z którą mamy do czynienia właśnie od lat osiemdziesiątych. Doszło więc do kontynuacji liberalnego paradoksu - powrót do ortodoksyjnej koncepcji pieniądza w czasach monetaryzmu wiązał się z kapitulacją państwa, jeśli chodzi o kontrolę nad systemem finansowym, to zaś pozwoliło na ogromny rozwój pieniądza kredytowego.

Jakie skutki wywołuje taka sytuacja? Chociaż w Wielkiej transformacji Polanyi analizuje utowarowienie pieniądza przez pryzmat powiązania jego wartości ze złotem, cytat o powodzi i suszy, który został przytoczony na wstępie tego rozdziału, może odnosić się również do wpływu, jaki sektor finansowy wywiera na sferę realną gospodarki we współczesnym kapitalizmie. Tak jak kiedyś, w czasach wielkiej transformacji, narody zostały uzależnione od fluktuacji kursów walutowych, tak dzisiaj kluczowe znaczenie dla rozwoju danego państwa ma zaufanie inwestorów do stabilności jego finansów publicznych, m.in. to ono determinuje wysokość kosztów obsługi długu publicznego. Jak pokazali Seccareccia i Correa (2015), współczesny system finansowy w wielu aspektach przypomina system waluty złotej sprzed drugiej wojny światowej. Posługując się przykładem Unii Europejskiej, autorzy pokazują, że euro stało się rodzajem drogocennego towaru deficytowego. Niczym złoto, pozbawiło państwa narodowe władzy nad pieniądzem narodowym. Według autorów koncepcja strefy euro opiera się na ortodoksyjnej teorii pieniądza, dlatego wśród głównych zalet wspólnej waluty liberalni ekonomiści wskazują przede wszystkim na obniżenie kosztów transakcyjnych. Podobnie jak złoto, euro jest kryzysogenne, ponieważ nie jest elastyczne, tzn. łączy pieniądz z pewnymi ,zewnętrznymi” i arbitralnymi kryteriami fiskalnymi i monetarnymi (m.in. zawartymi w traktacie $\mathrm{z}$ Maastricht). W trakcie kryzysu wymusza więc politykę oszczędnościową (Seccareccia i Correa, 2015, s. 9-10).

Można znaleźć więcej podobnych analogii między systemem waluty złotej a współczesnym rynkiem walutowym. Z pewnością dobrym przykładem byłaby sytuacja państw Ameryki Południowej, w których kluczową rolę odgrywa dolar (np. Argentyna) lub ogólniej sytuacja zależności między krajami rozwijającymi się a kapitałem z krajów centrum. Kluczowa w tym wszystkim jest jednak relacja podporządkowania między państwem a rynkami finansowymi.

Co stanowi o sile współczesnych haute finance? Wydaje się, że handel pieniądzem. Rynki finansowe stanowią najlepszy przykład utowarowienia pieniądza, albowiem umożliwiają inwestorom handel różnymi „formami” pieniądza w celu osiągnięcia większej płynności. Chodzi w tym przypadku przede wszystkim o „upłynnienie” zobowiązań sektora produktywnego finansowanego przez sektor kapitałowy, który emituje w tym celu własne zobowiązania - w postaci różnego rodzaju produktów giełdowych (np. SIV). Mają one stać się ,substytutem «waluty i monet» emitowanych przez rząd", a więc ,środkiem płatności, który może być wykorzystany do nabywania dóbr i usług od reszty sektora prywatnego" (Kregel, 2012, s. 2). Aktywa są bowiem posiadanymi przez graczy giełdowych znakami własności owych zobowiązań, którymi można handlować i zamieniać je na gotówkę (są to tzw. zapisy IOU - I owe you) (Wray, 2019, s. 14, 18). Nawiązując do Henry’ego Dunninga Macleoda, można powiedzieć, że pieniądz to właściwie 
symbol stwierdzający własność czyjegoś zadłużenia. Jak zaznacza szkocki ekonomista, ,[w]ielkim współczesnym odkryciem było zauważenie, że długi są towarami, które da się sprzedawać" (Macleod, 1866, s. 91). Ten towar przyjmuje właśnie postać aktywa (Commons, 1959, s. 397). Sprzedażą oraz kupnem aktywów zarządzał do tej pory system bankowy (Macleod, 1866, s. 91). Współcześnie coraz większe znaczenie odgrywają pośrednicy finansowi (shadow banking), którzy opierają swój model biznesowy na spekulacji i często prowadzą działalność bez jakiegokolwiek powiązania ze sferą produktywną gospodarki (Mazzucato, 2018). System, w którym tego typu instytucje zdobyły ogromną władzę, Susan Strange nazwała kapitalizmem kasyna. Zakłada on z jednej strony wprowadzenie systemów informatycznych przeprowadzających automatyczne transakcje spekulacyjne, a z drugiej - wiąże się z rozwojem instytucji niebankowych, które zajęły się działalnością kredytową. Nie podlegają one jednak takiej samej kontroli, jak banki, dlatego mogą bez przeszkód kreować nowy pieniądz (Strange, 1997, s. 45). System oparty na spekulacji jest niestabilny, ponieważ prowadzi do baniek cenowych, zaś po ich pęknięciu - do deflacji długu i kryzysu (zob. Macleod, 1866, s. 99).

Powołując się na powyższą konstatację, można więc powiedzieć, że gospodarka rynkowa spowodowała podporządkowanie sfery realnej sferze finansowej. Właśnie dlatego, jak ujął to Hyman Minsky, współczesne kryzysy są kryzysami finansowymi (Wray, 2015, s. 31). Nadpodaż pieniądza w czasach rozkwitu związana jest z kreacją nowych instrumentów finansowych. Taka spekulacja wpływa nie tylko na wzrost cen aktywów, ale również surowców czy żywności, co może być powodem powszechnego głodu w społeczeństwie (s. 144). Z kolei w przypadku kryzysu zniszczona zostaje podaż pieniądza, przez co sfera realna zostaje odcięta od finansowania. Do akcji musi wejść wówczas państwo, które za pomocą programów ratunkowych ogranicza władzę rynku (Polanyi, 2010, s. 232; Savevska, 2019, s. 33).

Widać więc wyraźnie, że w myśl teorii Polanyiego komodyfikacja pieniądza powoduje, iż kryzys staje się immanentnym elementem systemu rynkowego. Autora Wielkiej transformacji można więc uznać za jednego z fundatorów heterodoksyjnej koncepcji endogeniczności kryzysów, która zakłada, że sama struktura sektora finansowego jest przyczyną kryzysów gospodarczych (Wray, 2015, s. 58). W tym przypadku kluczowym zadaniem wydaje się już nie opisanie samej ortodoksyjnej ideologii pieniądza jako towaru, ale przeanalizowanie praktycznych skutków, jakie ona niesie. Utowarowienie pieniądza wymaga bowiem deregulacji oraz wycofania się państwa z kontroli rynków finansowych. Fundamentalizm rynkowy - zdaniem Blocka i Somers (2020, s. 193) współczesna odmiana dawnego liberalizmu - każe traktować pieniądz tak, jakby jego podaż miała się zrównać z popytem. To ideologiczne założenie opiera się na monetarystycznej tezie, że popyt na pieniądz, „tak jakby był on towarem jak każdy inny” (Strange, 1997, s. 84) jest stabilny, zaś podaż pieniądza jest egzogenna (ustalana przez bank centralny) i to ona określa wartość pieniądza. Jak wskazuje Susan Strange (1977, s. 64), ortodoksja nie może wyjaśnić kryzysów finansowych, albowiem 
[p]ieniądze (są przez nią - JK) traktowane jako kolejny towar, z podażą korespondującą popytowi (...). Jest to jednak mylące, ponieważ kreacja pieniądza (przede wszystkim w formie kredytu) daje władzę, jak i bogactwo kreatorowi. Istnieje więc ciągłe napięcie między prywatnymi kreatorami i publicznymi, między bankami (dzisiaj już nie tylko) i państwem.

Tam, gdzie ortodoksja widzi rzecz, tam teoria pieniądza endogenicznego dostrzega relację władzy. Pozostawienie coraz większej przestrzeni na kreację pieniądza sferze komercyjnej jest więc symptomem zmiany ośrodka władzy. Według Mary Mellor (2010, s. 31) sektor komercyjny „sprywatyzował system pieniądza”. Autorka zaznacza, że od połowy XX wieku udział państwowo kreowanego pieniądza fiducjarnego jest marginalny. Towarzyszy temu wycofanie się państwa z kontroli pieniądza oraz podporządkowanie go prawom rynku (zob. Mellor, 2010, s. 19). Jednak, jak już zostało wspomniane wyżej, system pieniądza jest gwarantowany przez państwo i to ono odpowiada za jego wartość. Można więc za Polanyim powiedzieć, że pozostawienie pieniądza poza obrębem działań Lewiatana jest zabiegiem sztucznym. Dowiódł tego kryzys z 2008 roku, podczas którego państwo poniosło koszty spekulacyjnych decyzji prywatnych inwestorów (s. 25, 27).

Ówczesny kryzys okazał się „momentem Minsky’ego” (Wray, 2015, s. 138). Jak wskazuje Fred Block (2016, s. 7), można zauważyć znaczące podobieństwa między hipotezą niestabilności finansowej Minsky’ego a teorią towarów fikcyjnych Polanyiego. Z perspektywy ekonomii neoklasycznej banki są pośrednikami między depozytariuszami a pożyczkobiorcami, zaś podaż pieniądza określana jest przez wielkość bazy monetarnej, którą kontroluje bank centralny. Zarówno Polanyi, jak i Minsky uważają, że to banki tworzą podaż pieniądza: ,[...] ludzie nie rozumieją, że pieniądze są towarem fikcyjnym i że banki dostały licencje na produkcję kredytu” (Block, 2016, s. 8). Coraz większe znaczenie mają jednak współcześnie instytucje, które oficjalnie takiej licencji nie dostały, należące do tzw. sektora shadow banking. Zajmują się one produkcją - słowami Jana Kregela - „fikcyjnej płynności”, a więc płynności, która powstaje wraz z handlem produktami zadłużeniowymi na rynkach wtórnych. Jedynym motywem takiego obrotu jest sprzedaż owych produktów z zyskiem. Nie jest to więc płynność powstająca wraz z udzieleniem komuś kredytu na sfinansowanie konkretnej inwestycji w sferze produktywnej (Kregel, 2012, s. 11; Block, 2016, s. 8). Powstanie tej fikcyjnej płynności wiąże się z performatywnym działaniem inwestorów, którzy zachowują się tak, jakby pieniądz sam w sobie był inwestycją. Jak wskazuje Mariana Mazzucato (2018, s. 120), na giełdzie pieniądz nie jest postrzegany ,jako środek wymiany, ale jako cel sam w sobie". Uwidacznia się to przede wszystkim w okresie optymizmu giełdowego, ,[k]ażdy menedżer pieniądza musi pobić średni zwrot, aby zachować klientów, jest to oczywiście statystycznie niemożliwe" (Wray, 2015, s. 142). Samo jednak dążenie do takiego wysokiego zwrotu z ,inwestycji” jest destabilizujące, ponieważ - zgodnie z teorią Minsky'ego - powoduje, że inwestorzy zajmują coraz bardziej ryzykowne pozycje. W skrajnym, przedkryzysowym przypadku coraz częściej mamy do czynienia z tzw. pozycją Ponzi, w ramach której oczekiwane zyski nie pokrywają nawet oprocentowania kredytu. 
Inwestor musi więc zaciągać kolejne zobowiązania, aby spłacić raty dawnych kredytów (s. 32). Pęd ku wyższym zyskom zatrzymać może jedynie kryzys - w czasach hossy nikt nie chce pozostać z tyłu.

\title{
5. Podsumowanie - pieniądz jako dobro publiczne
}

Według Karla Polanyiego pieniądz nie jest ani rzeczą, ani towarem. Jest za to relacją społeczną opartą na społecznej akceptacji relacji długu, która jest zapewniana przez państwo. Wydaje się, że jest to najważniejszy element odróżniający teorię Polanyiego zarówno od ekonomii neoklasycznej, jak i marksistowskiej. Obie te teorie akceptują metaliczną koncepcję pieniądza, przy czym liberalizm przyjmuje tezę o neutralności pieniądza, zaś marksizm wskazuje na jego alienującą moc. Polanyi zauważył, że pieniądz wiąże się przede wszystkim ze społecznie produkowaną relacją długu, nie zaś z barterem. Pieniądz nie jest towarem, albowiem ,stanowi znak siły nabywczej, która z zasady wcale nie jest produkowana, lecz powstaje za pośrednictwem mechanizmu bankowości czy finansów publicznych" (Polanyi, 2010, s. 88). Jest on więc znakiem pewnej abstrakcyjnej wartości, potwierdzonym przez państwo i banki, dzięki któremu można spłacić zadłużenie lub zakupić konkretne produkty na rynku. Teza o jego abstrakcyjnej naturze stanowi podwaliny koncepcji pieniądza jako dobra publicznego, rozwijanej w ramach nurtu nowoczesnej teorii monetarnej (MMT). Właśnie dlatego podstawową różnicę między marksizmem a teorią Polanyiego można zobrazować, porównując założenia marksizmu oraz MMT. Scott Ferguson (2018) zauważa, że

\begin{abstract}
marksizm przypisuje najwyższy poziom istnienia bezpośrednim materialnym relacjom, postrzegając pieniężną abstrakcję jako [...] wyobcowanie świadomych lokalnych wspólnot. Z kolei MMT opiera zbiorową egzystencję na politycznym centrum społeczności i utrzymuje, że pieniądze są niewyczerpanym narzędziem rządowym, służącym uspołecznieniu stosunków produkcji i dystrybucji na odległość.
\end{abstract}

To polityczne centrum - państwo - jest kluczowym elementem w teorii Polanyiego. Rynek został przecież „wykorzeniony” za pomocą środków politycznych. Ekonomiście nie chodzi więc o postawienie się po którejś ze stron politycznej dychotomii państwo - rynek, ale o przywrócenie państwu jego naturalnej - stabilizującej - roli. Można więc powiedzieć, że utopijne kontrruchy, które towarzyszyły „rynkowej rewolucji”, występowały właśnie przeciwko tej dychotomii. Widać więc wyraźnie, że teoria Polanyiego stanowi swoisty pomost, który pozwala połączyć podstawowe tezy socjologii wiedzy (o tzw. „nowej socjologii idei” opartej na odkryciach Polanyiego zob. Block i Somers, 2020, s. 200) z ekonomiczną analizą niestabilności finansowej kapitalizmu. Kontrruch oraz kryzys są dwoma rodzajami zjawisk uniemożliwiających prywatyzację pieniądza, odsłaniających jednocześnie jego prawdziwy charakter jako dobra publicznego. 


\section{Bibliografia}

Benedict, R. (2007). Północno-zachodnie wybrzeże Ameryki. W: E. Nowicka, M. Głowacka-Grajper (red.), Świat człowieka, świat kultury. Antologia tekstów klasycznej antropologii (s. 372-402). Warszawa: Wydawnictwo Naukowe PWN.

Block, F. (2016). The Contradictory Logics of Financialization: Bringing Together Hyman Minsky and Karl Polanyi. Politics \& Society, 44(1), 3-13.

Block, F., \& Somers, M. (2020). Karl Polanyi. Krytyka wolnorynkowego fundamentalizmu. Poznań: Wydawnictwo Ekonomiczne „Heterodox”.

Codere, H. (1968). Money-exchange systems and a theory of money. Man, 3(4), $557-577$.

Commons, J. (1959). Institutional economics; Its place in political economy. Madison: University of Wisconsin Press.

Dalton, G. (1961). Economic theory and primitive society. American Anthropologist, 63(1), 1-25.

Drucker, P. F. (1993). Concept of the Corporation. New York: Routledge.

Ferguson, S. (2018). Money's Laws of Motion. https://arcade.stanford.edu/blogs/ moneys-laws-motion

Graeber, D. (2018). Dlug. Pierwsze pięć tysięcy lat. Warszawa: Wydawnictwo Krytyki Politycznej.

Ingham, G. (2013). The Nature of Money. Cambridge: Polity Press.

Jessop, B. (2019). A Polanyian paradox: Money and credit as fictitious commodities, financialization, finance-dominated accumulation, and financial crises. W: R. Atzmüller, B. Aulenbacher, U. Brand, F. Décieux, K. Fischer, B. Sauer (red.), Capitalism in Transformation: Movements and Countermovements in the 21st Century (s. 79-90). Cheltenham: Edward Elgar Publishing.

Kassner, M. (2019). Pragmatyzm i radykalny liberalizm. Studium filozofii politycznej Johna Deweya. Toruń: Wydawnictwo Naukowe Uniwersytetu Mikołaja Kopernika.

Keynes, J. M. (2013). Treatise on money: Pure theory of money. Vol. I. London: Routledge.

Kozubowski, J. (2018). Ciągłość czy zerwanie? Przyczynek do rozważań na temat historii polskiej myśli socjalistycznej XIX wieku. Praktyka Teoretyczna, 29(3), 51-77.

Kregel, J. (2012). Regulating the financial system in a Minskyian perspective. http://bibliotecadigital.fgv.br/dspace;/bitstream/handle/10438/16283/Panel $\% 204 \% 20-\% 20 J a n \% 20 K r e g e l \_0 . p d f$ ?sequence=1\&isAllowed $=y$ 
Lewicki, M. (2019). Społeczne życie hipoteki. Warszawa: Wydawnictwo Naukowe Scholar.

Macleod, H. D. (1866). The Theory and Practice of Banking. Vol. I. London: Longmans, Green, Reader \& Dyer.

Mannheim, K. (2008). Ideologia i utopia (J. Miziński, tłum.). Warszawa: Wydawnictwo Aletheia.

Marks, K. (1951). Kapitat, t. 1. Warszawa: Książka i Wiedza.

Maucourant, J. (1995). The substantive economy of money: Karl Polanyi in the tradition of "old institutionalism". https://halshs.archives-ouvertes.fr/file/ index/docid/569422/filename/WP_Walras_nA_177.pdf

Mazzucato, M. (2018). The value of everything: Making and taking in the global economy. New York: PublicAffairs.

Mellor, M. (2010). The future of money: From financial crisis to public resource. London: Pluto Press.

Mill, J. S. (1885). Principles of political economy. London: Longmans, Green, \& Co.

Polanyi, K. (1957). Aristotle discovers the economy. W: K. Polanyi, C. M. Arensberg, H. W. Pearson (red.), Trade and market in the early empires: Economies in history and theory (s. 64-96). Glencoe: Free Press and Falcon's Wing Press.

Polanyi, K. (1977). The Livelihood of Man. New York: Academic Press.

Polanyi, K. (2010). Wielka transformacja (M. Zawadzka, tłum.). Warszawa: Wydawnictwo Naukowe PWN.

Savevska, M. (2019). The fictitious commodification of money and the Euro experiment. Culture, Practice \& Europeanization, 4(1), 29-42.

Schumpeter, J. A. (2006). History of economic analysis. London: Routledge.

Seccareccia, M., \& Correa, E. (2015). Supra-National Money and the Euro Crisis: Lessons from Karl Polanyi. Forum for Social Economics, 46(3), 1-23. https://doi.org/10.1080/07360932.2015.1075896

Simmel, G. (2012). Filozofia pieniądza (A. Przyłębski, tłum.). Warszawa: Wydawnictwo Aletheia.

Skrzypek, M. (1992). Rozwój teorii fetyszyzmu od De Brossesa do Freuda. W: Ch. de Brosses, O kulcie fetyszów (M. Skrzypek, tłum.) (s. VII-XXX). Warszawa: PAN.

Strange, S. (1997). Casino Capitalism. Manchester: Manchester University Press.

Walter, T., \& Wansleben, L. (2020). How central bankers learned to love financialization: The Fed, the Bank, and the enlisting of unfettered markets in the conduct of monetary policy. Socio-Economic Review, 18(3), 625-653. https://doi.org/10.1093/ser/mwz011

Wennerlind, C. (2001). Money talks, but what is it saying? Semiotics of money and social control. Journal of Economic Issues, 35(3), 557-574. 
Wray, R. L. (2015). Why Minsky matters: An introduction to the work of a maverick economist. Princeton: Princeton University Press.

Wray, R. L. (2019). Nowoczesna teoria monetarna MMT (P. Umiński, tłum.). Poznań: Wydawnictwo Ekonomiczne „Heterodox”. 